\title{
PELATIHAN SAP 2000 DALAM PERENCANAAN KONSTRUKSI GEDUNG BETON BERTULANG DAN BAJA TAHAN GEMPA BERDASARKAN SNI 03-1726-2012
}

\author{
Widya Apriani
}

\begin{abstract}
ABSTRAK
Di era MEA saat ini dituntut berbagai keahlian dan keterampilan setiap lulusan teknik sipil. Namun pada kenyataannya masih sangat banyak lulusan S1 teknik sipil yang belum memiliki keterampilan sebagai bekal di dunia kerja. Akibatnya lulusan sulit bersaing di dunia kerja baik lokal dan nasional. Salah satu keterampilan yang dibutuhkan adalah penguasaan software analisis struktur untuk perencanaan konstruksi gedung. Oleh karena itu diperlukan adanya pelatihan perencanaan konstruksi gedung beton bertulang dan baja tahan gempa Berdasarkan SNI 03-1726-2012 menggunakan bantuan program SAP 2000. Program ini merupakan program yang dilakukan untuk meningkatkan kompetensi softskill lulusan teknik sipil yang ada di Pekanbaru. Pelatihan ini dilakukan untuk menambah wawasan dan softskill, serta meningkatkan minat serta kompetensi lulusan dalam konstruksi bangunan gedung tahan Gempa dengan peraturan terbaru gempa SNI 03-1726-2012. Pelatihan SAP 2000 dilaksanakan selama 6 kali pertemuan dimulai dari tanggal 09 April 2016 hingga 07 Mei 2016 di Ruang kelas Fakultas Teknik Universitas Lancang Kuning dengan jadwal yang rutin yaitu setiap hari kamis pukul 13.30 hingga 15.30. Peserta pelatihan berjumlah 37 orang yang merupakan lulusan teknik sipil yang ada di Pekanbaru. Metode pelaksanaan pelatihan adalah metode ceramah, diskusi dan praktek. Hasil yang dapai dicapai dari pelaksanaan kegiatan ini adalah pengetahuan peserta setelah dilaksanakan pelatihan diuji dengan dilakukan tes dengan indikator nilai (0-100). Setelah dilakukan penilaian dapat disimpulkan pengetahuan peserta setelah mengikuti pelatihan sebesar $84 \%$. Oleh karena itu dapat dikatakan bahwa peserta pelatihan mengalami peningkatan pengetahuan dan mampu memahami materi pelatihan dasar tentang program SAP 2000. Hasil Analisis tes hasil belajar untuk mengetahui persentase pencapaian ketuntasan peserta.sebesar $100 \%$.
\end{abstract}

Kata kunci: Konstruksi,Gedung, SAP 2000, SNI -03-1726-2012

\section{Pendahulan}

\subsection{Analisis Situasi}

Sektor jasa konstruksi merupakan satu diantara dua belas sektor jasa yang akan diintegrasikan dalam MEA. Persiapan untuk menghadapi persaingan konstruksi di era MEA salah satunya adalah dengan mencetak tenaga kerja konstruksi yang handal dan kompeten. Terdapat faktor yang mempengaruhi daya saing sektor jasa konstruksi diantaranya kapasitas sumber daya manusia. Dalam rangka memenuhi tenaga kerja yang memiliki kompetensi dan melahirkan tenaga ahli yang berkualitas maka diperlukan Pelatihan Berbasis Kompetensi Bidang Jasa Konstruksi (Permen PU NO 14,2014). 
Olehkarena itu salah satu usaha yang dapat dikembangkan kepada masyarakat jasa konstruksi adalah meningkatkan kemampuan penerapan ilmu struktur teknik sipil.

Kebutuhan menggunakan alat bantu berupa program komputer tidak bisa lepas jika akan menganalisis suatu desain struktur Structural Analysis Program (SAP 2000) adalah salah satu program yang paling umum digunakan untuk menganalisis struktur konstruksi gedung beton bertulang ataupun baja. Dengan menggunakan program tersebut maka proses analisa struktur Perancangan Bangunan Tahan Gempa sesuai SNI 03-1726-2012 dapat dilakukan cepat dan hasilnya ditampilkan secara visual dengan lebih baik. Untuk memiliki keterampilan tersebut dapat dilakukan dengan belajar otodidak melalui internet dan dapat juga dengan mengikuti pelatihan atau kursus. Sabariman (2013) telah melakukan kegiatan pelatihan SAP 200 pada mahasiswa dan diperoleh hasil analisis bahwa peningkatan hasil belajar mahasiswa setelah menggunakan media tutorial SAP2000 versi 15 meningkat, ditunjukkan dari persentase mahasiswa yang lulus tes sebesar 58,3 \% pada pretest menjadi $83,3 \%$ pada posttest. Oleh karena itu perlu dikembangkan kegiatan pelatihan program SAP tersebut dengan metode yang berbeda.

\subsection{Permasalahan Mitra}

Kerelevanan antara kebutuhan dunia kerja dengan kompetensi yang diperoleh di dunia akademis merupakan hal yang penting dimiliki oleh lulusan dan mahasiswa teknik sipil. Dunia kerja membutuhkan tenaga kerja yang memiliki softskill diantaranya mampu mengoperasikan software analisa struktur. Dunia akademis menuntut lulusan untuk memahami konsep analisis struktur secara klasik. (dewobroto,2014). Namun kompetesi mahasiswa dan lulusan teknik sipil dalam softskill masih rendah sehingga hal inilah yang menjadi permasalahan yang akan diangkat pada penelitian ini.

\subsection{Tujuan}

Pada akhirnya tujuan dari kegiatan pengabdian ini adalah untuk meningkatkan kemampuan dan menambah wawasan ilmu pengetahuan struktur berbasis komputer kepada mahasiswa dan alumni teknik sipil dalam mempersiapkan diri memasuki dunia kerja.

\section{Metode}

Pelatihan SAP 2000 dilaksanakan selama 6 kali pertemuan dimulai dari tanggal 09 April hingga 07 Mei 2016 di ruang Kelas Fakultas Teknik Universitas Lancang Kuning dengan jadwal yang rutin yaitu setiap hari kamis pukul 13.30 hingga 15.30. Peserta pelatihan 
berjumlah 37 orang yang merupakan lulusan teknik sipil dan mahasiswa yang ada di Pekanbaru.

Metode yang digunakan pada kegiatan pelatihan dirancang agar peserta dapat memahami secara komprehensif materi yang disampaikan, sehingga dapat dimplementasikan secara aplikatif dalam dunia kerja. Adapun metode yang digunakan adalah: 1. Persiapan pelatihan, meliputi mempersiapkan brosur kegiatan. bahan pelajaran berupa modul, menyusun rencana waktu pelatihan yaitu berisi pengetahuan tentang tujuan penelitian, alat bantu dan media pelatihan serta jenis evaluasi yang akan digunakan, fasilitas pelatihan dan menyiapkan administrasi pelatihan seperti daftar hadir peserta.

2. Pelaksanaan pelatihan, meliputi kegiatan ceramah, diskusi dan praktek. Pada pelatihan ini akan diajarkan cara pengoperasian software. Walaupun penggunaannya cukup sederhana, karena berbasis visual, tetapi tetap harus diimbangi dengan pengetahuan dasar pemakain program dan ilmu analisis struktur klasik(dewobroto,2013). Peserta diberikan bimbingan untuk mempraktekkan program SAP 2000 sesuai dengan materi yang diberikan.
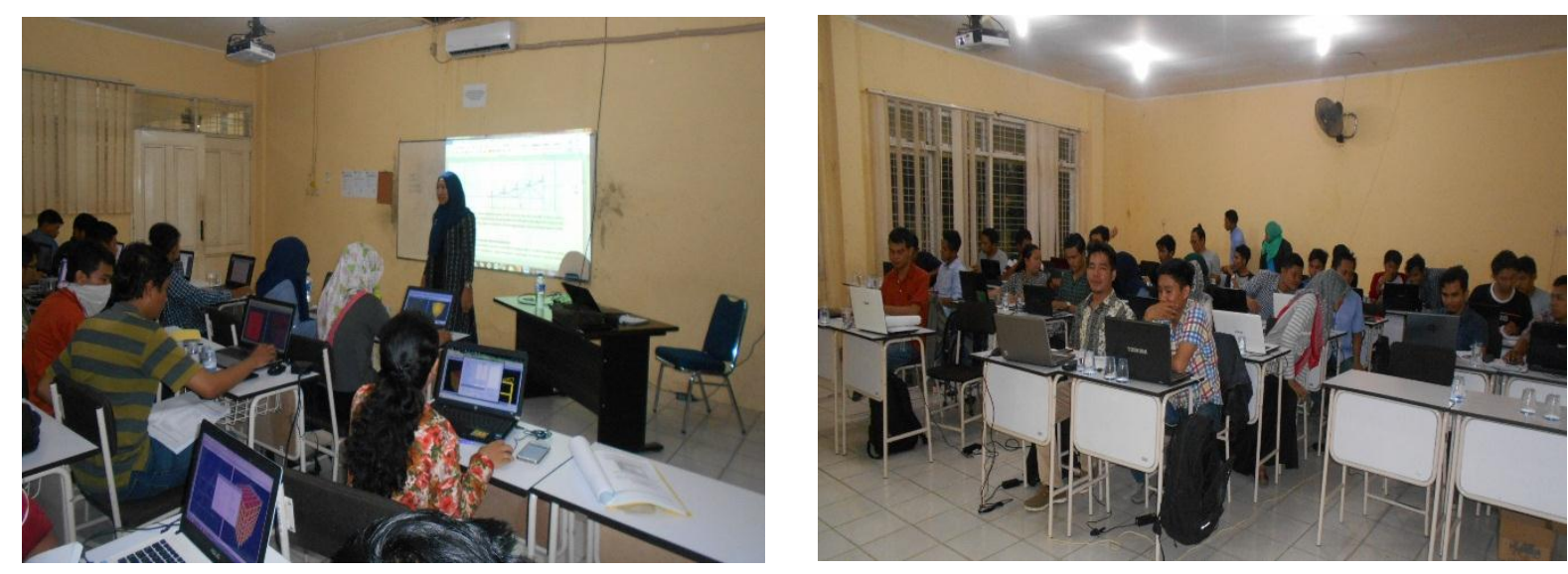

Gambar 1. Pelaksanaan Pelatihan pada sesi penyampaian materi

3. Evaluasi, yaitu mengukur pencapaian setiap peserta yang dapat diukur selama pelaksanaan pelatihan tersebut berlangsung dengan tes, Hasil yang dievaluasi dari pelaksanaan kegiatan ini adalah pengetahuan peserta setelah dilaksanakan pelatihan diuji dengan dilakukan tes dengan indikator nilai (0-100). 
Adapaun materi pokok disampaikan dalam tutorial analisis portal 3D bantuan SAP2000 sebagai berikut:
a) Pengenalan SAP 2000
b) Portal Beton bertulang 3D
c) Portal Baja 3D
d) Analisis beban gempa SNI 1726-2012
e) Analisis statik ekuivalen
f) Analisis gempa dinamik (Response Spektrum)
g) Interpretasi output/hasil analisis struktur

5. Memberikan sertifikat kepada peserta yang dinyatakan lulus tes yang dikeluarkan oleh prodi teknik sipil sebagai pihak yang berwenang.

\subsection{Teknik Analisis Data}

Teknik analisis data yang digunakan adalah analisis kuantitatif deskriptif yaitu analisis yang berhubungan dengan angka, baik angka yang diperoleh dari pencacahan maupun penghitungan.(Muhson,2010) Data yang telah diperoleh dari pencacahan selanjutnya diolah dan disajikan dalam bentuk yang lebih mudah dimengerti oleh pengguna data tersebut. Sajian data kuantitatif sebagai hasil analisis kuantitatif dapat berupa angkaangka maupun gambar-gambar grafik. Metode analisis data yang digunakan dalam penelitin ini adalah berupa persentase. Hal yang diukur meliputi tingkat pemahaman terhadap suatu materi dan tingkat ketuntasan peserta.

\subsubsection{Tingkat pemahaman peserta}

Tingkat pemahaman peserta terhadap suatu materi dihitung menggunakan rumus berikut:

$$
\text { persentase pemahaman }=\Sigma\left(\frac{\text { jumlah responden yang benar }}{\text { jumlah seluruh responden }}\right) \times 100 \%
$$

\subsubsection{Analisis Tingkat ketuntasan Peserta}

Analisis tes hasil belajar mahasiswa untuk mengetahui persentase pencapaian ketuntasan peserta. Pencapaian ketuntasan mahasiswa dapat dihitung dengan rumus berikut:

Ketuntasan peserta $=\left(\frac{\text { jumlah skor yang dicapai }}{\text { jumlah skor maksimal }}\right) \times 100 \%$ 
Tabel 1. Kriteria interpretasi skor

\begin{tabular}{ll}
\hline $\begin{array}{l}\text { Tingkat } \\
\text { Pencapaian } \\
(\%)\end{array}$ & Kualifikasi \\
\hline $81 \%-100 \%$ & Sangat Baik \\
$61 \%-80 \%$ & Baik \\
$41 \%-60 \%$ & Cukup \\
$21 \%-40 \%$ & Kurang \\
$0 \%-20 \%$ & Sangat Kurang \\
\hline
\end{tabular}

\section{Hasil dan Pembahasan}

\subsection{Tingkat pemahaman peserta}

Pada bab ini akan diuraikan hasil dan analisis data penelitian yang diperoleh selama pelaksanaan pelatihan sap 2000 dalam perencanaan konstruksi gedung beton bertulang dan baja tahan gempa berdasarkan SNI 03-1726-2012. Dari hasil studi diperoleh gambaran tingkat pemahaman mahasiswa terhadap materi SAP2000 sebagai berikut:

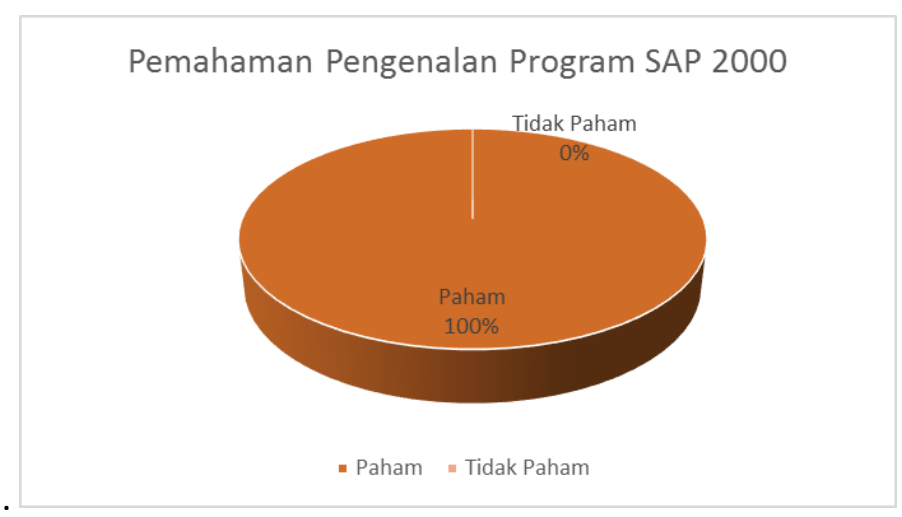

Gambar 2. Persentase hasil belajar peserta terhadap pemahaman program SAP 2000

Tingkat pemahaman Program SAP 2000 diindikasikan dengan pemahaman terhadap cara pengoperasian program dan pengenalan fungsi program. Berdasarkan analisis diperoleh persentase tingkat pemahaman peserta terhadap Program SAP 2000 adalah 100\%. 


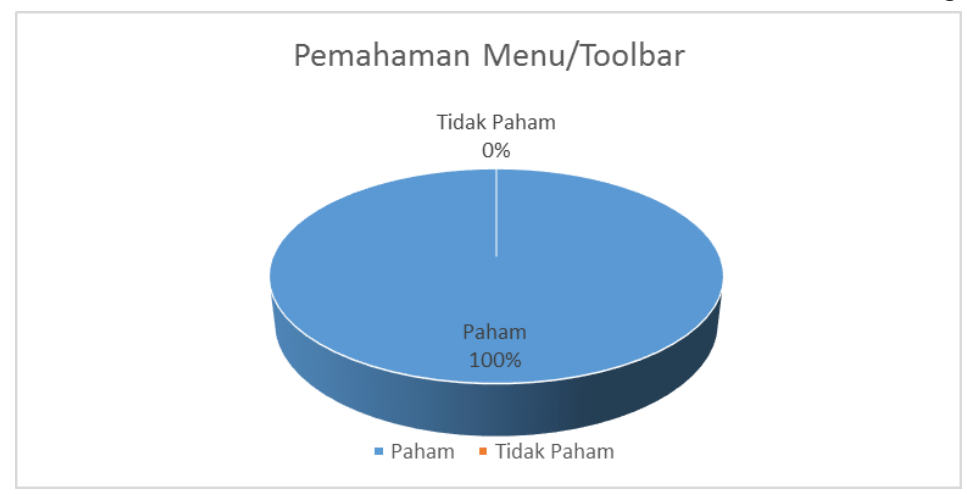

Gambar 3. Persentase hasil belajar peserta terhadap pemahaman menu yang terdapat pada program

Tingkat pemahaman bagian ini diindikasikan dengan pemahaman terhadap menu yang terdapat pada program seperti penetapan sumbu koordinat, toolbar new model, define material, define section properties, define load pattern, define load combination, dsb. Berdasarkan analisis diperoleh tingkat pemahaman peserta terhadap menu/toolbar adalah $100 \%$.

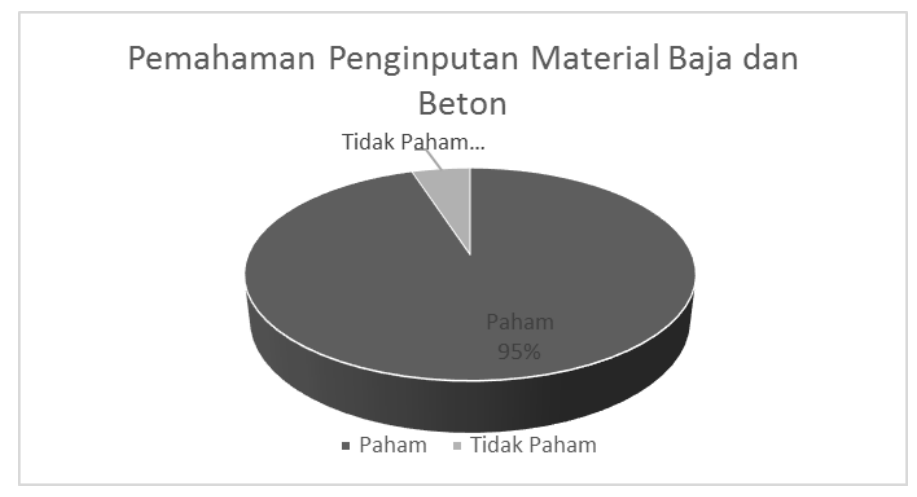

Gambar 4. persentase hasil belajar peserta terhadap pemahaman penginputan material baja dan beton

Tingkat pemahaman bagian ini diindikasikan dengan pemahaman terhadap cara penginputan material baja dan beton, meliputi input berat jenis beton, modulus elastisitas beton, poisson rasio, modulus geser, kuat tekan beton rencana, kuat tarik leleh baja, dan kuat tarik putus baja. . Berdasarkan analisis diperoleh tingkat pemahaman peserta terhadap penginputan material baja dan beton sebesar 95\%. Faktor ketidak hadiran pada saat penyampaian materi dan penguasaan konsep material sturktur merupakan faktor ketidak pahaman sebesar 5\%. 


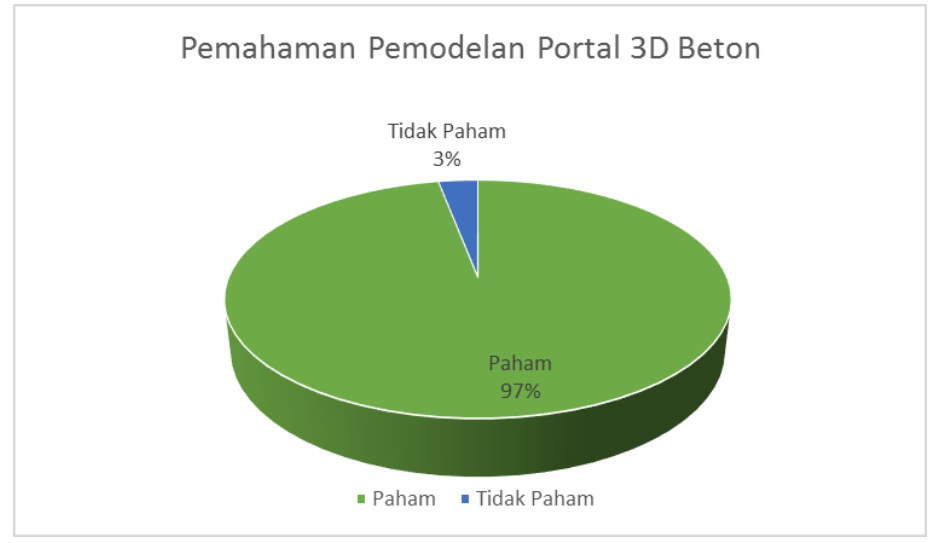

Gambar 5. Persentase hasil belajar peserta terhadap pemahaman pemodelan portal 3D beton

Tingkat pemahaman bagian ini diindikasikan dengan pemahaman terhadap cara pemodelan portal 3D beton meliputi cara pendefinisian penampang beton, cara memilih dan menginput tulangan, mendefinisikan selimut beton, dan cara menggambarkan portal 3D. Berdasarkan analisis diperoleh tingkat pemahaman peserta terhadap pemahaman pemodelan portal 3D sebesar 97\%. Faktor ketidak hadiran pada saat penyampaian materi, kurang memahami penjelasan instruktur dan penguasaan konsep desain struktur portal beton secara klasik merupakan faktor ketidak pahaman sebesar 3\%.

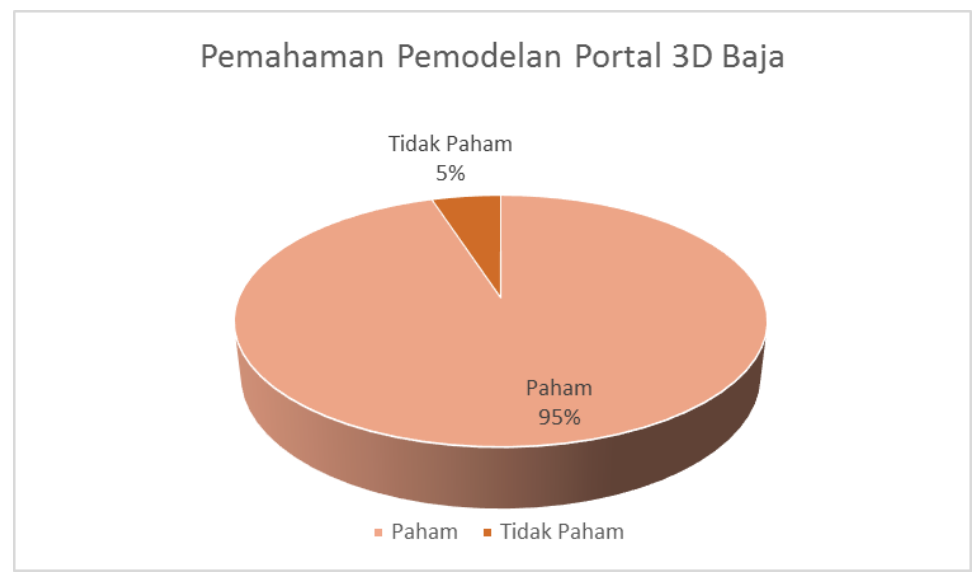

Gambar 6. Persentase hasil belajar peserta terhadap pemahaman pemodelan portal 3D baja

Tingkat pemahaman bagian ini diindikasikan dengan pemahaman terhadap cara pemodelan portal 3D stuktur baja, meliputi cara pendefinisian penampang baja, dan cara menggambarkan portal 3D. Berdasarkan analisis diperoleh tingkat pemahaman peserta 
sebesar $95 \%$. Faktor ketidak hadiran pada saat penyampaian materi, kurang memahami penjelasan instruktur dan penguasaan konsep desain struktur Portal baja secara klasik merupakan faktor ketidak pahaman sebesar 5\%.

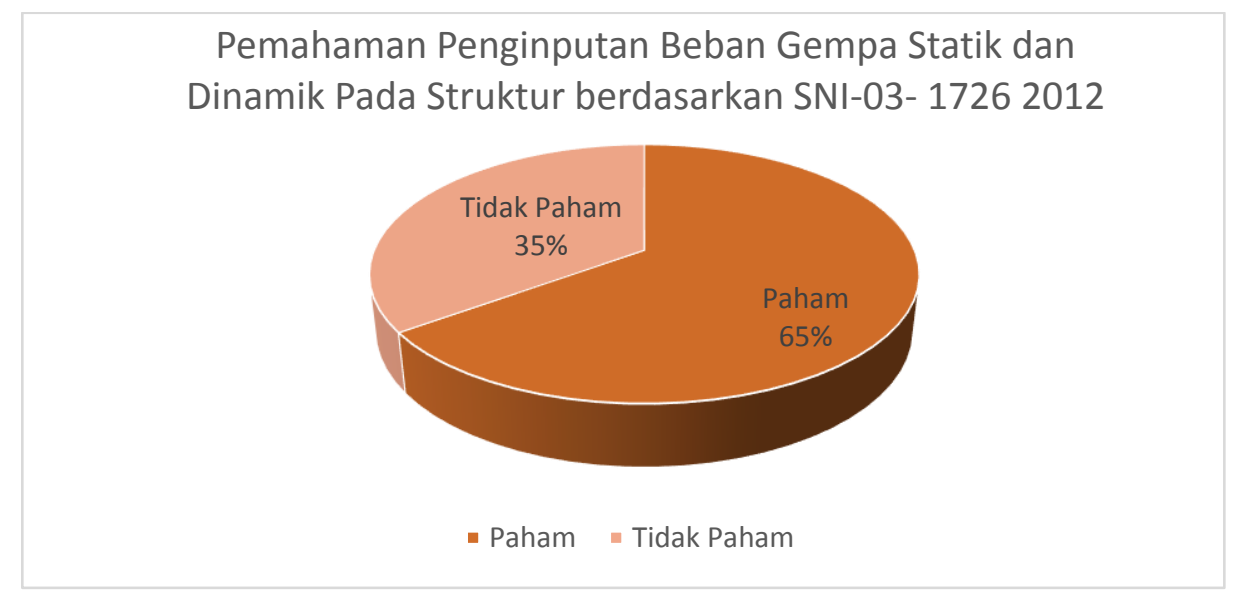

Gambar 7. Persentase hasil belajar peserta terhadap pemahaman penginputan beban gempa statik dan dinamik pada struktur berdasarkan SNI 03-1726-2012

Tingkat pemahaman bagian ini diindikasikan dengan pemahaman terhadap cara Penginputan Beban Gempa Statik dan Dinamik pada Struktur berdasarkan SNI 03-17262012, meliputi cara men-define beban gempa statik dan respons spectrum, define mass source, dan define scale factor. Berdasarkan analisis diperoleh tingkat pemahaman peserta sebesar 65\%. Faktor ketidakhadiran pada saat penyampaian materi, kurang memahami penjelasan instruktur dan penguasaan konsep desain struktur dengan SNI 0317262012 merupakan faktor ketidak pahaman sebesar 35\%.

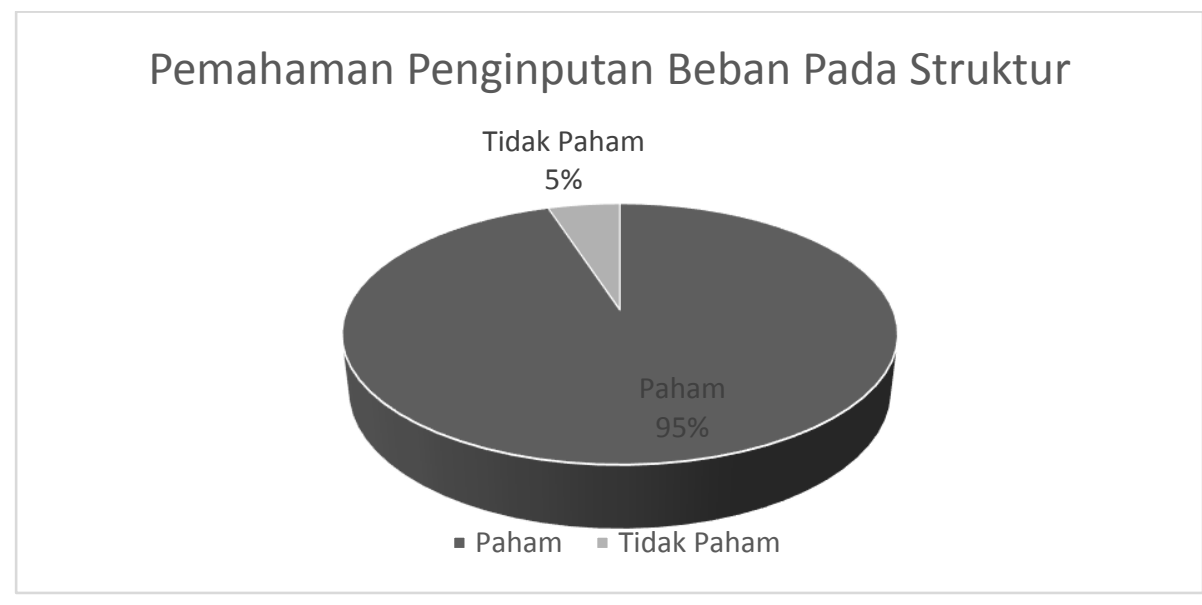

Gambar 8. Persentase hasil belajar peserta terhadap pemahaman penginputan beban pada struktur 
Tingkat pemahaman bagian ini diindikasikan dengan pemahaman penginputan beban pada struktur, meliputi cara mendefinisikan beban-beban yang ada, menentukan penyaluran beban pada struktur, dan mengaplikasikan kombinasi pembebanan. Berdasarkan analisis diperoleh tingkat pemahaman peserta sebesar 95\%. Faktor ketidak hadiran pada saat penyampaian materi dan kurang memahami penjelasan instruktur merupakan faktor ketidak pahaman sebesar 5\%.

\section{Pemahaman Analisis Struktur hasil running}

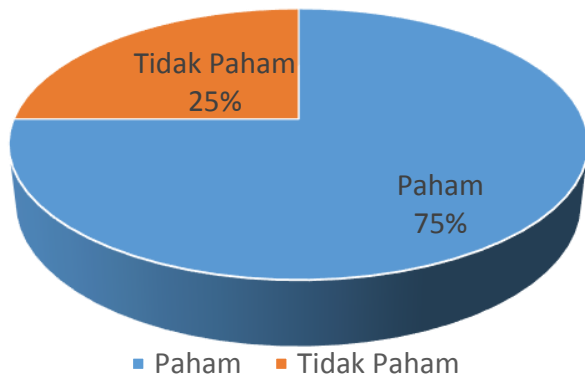

Gambar 9. Persentase hasil belajar Peserta terhadap Pemahaman Analisis Struktur hasil Running

Tingkat pemahaman bagian ini diindikasikan dengan pemahaman terhadap cara Analisis struktur hasil running, meliputi cara menset analysis optins dan run analysis, menampilkan deformasi strukur, menampilkan reaksi tumpuan,. Berdasarkan analisis diperoleh tingkat pemahaman peserta sebesar $75 \%$. Faktor ketidakhadiran pada saat penyampaian materi dan kurang memahami penjelasan instruktur merupakan faktor ketidak pahaman sebesar $25 \%$. 
Pemahaman membaca gaya dalam momen, geser, aksial dan lintang

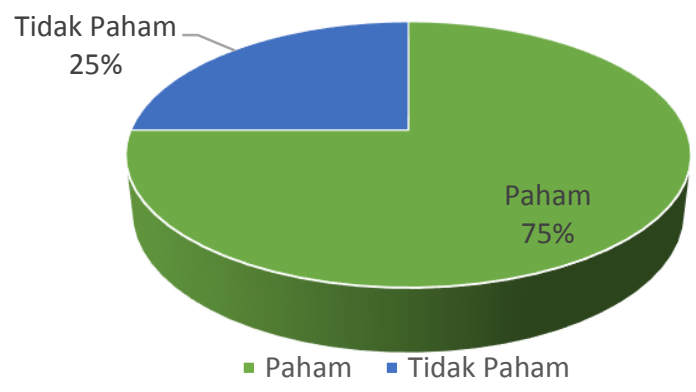

Gambar 10. Persentase hasil belajar Peserta terhadap pemahaman membaca gaya dalam momen, geser, aksial dan lintang

Tingkat pemahaman bagian ini diindikasikan dengan pemahaman membaca gaya dalam momen, geser, aksial dan lintang. Hal ini meliputi cara menampilkan gaya-gaya batang dan mampu mengartikan istilah di SAP dalam menentapkan gaya dalam Berdasarkan analisis diperoleh tingkat pemahaman peserta sebesar 75\%. Faktor ketidak hadiran pada saat penyampaian materi dan kurang memahami penjelasan instruktur merupakan faktor ketidak pahaman sebesar $25 \%$.

\section{Pemahaman Desain Profil Elemen Struktur balok dan kolom}

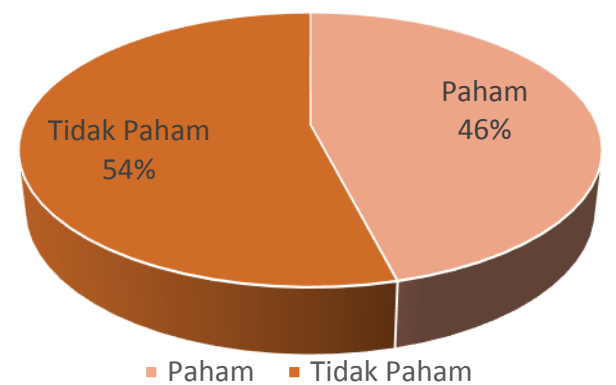

Gambar 11. Persentase hasil belajar peserta terhadap pemahaman desain profil elemen struktur balok dan kolom (portal)

Tingkat pemahaman bagian ini diindikasikan dengan pemahaman cara mendesain profil elemen struktur balok dan kolom (portal). Hal ini meliputi cara mengaplikasikan desain struktur, memilih jenis peraturan, menset profil yang ekonomis. Berdasarkan analisis 
diperoleh tingkat pemahaman peserta sebesar 46\%. Faktor intensitas latihan, pemahaman konsep analisis struktur secara kalsik dan kurang memahami penjelasan instruktur merupakan faktor ketidak pahaman sebesar $54 \%$.

\subsection{Analisis Tingkat ketuntasan Peserta}

Analisis tes hasil belajar mahasiswa untuk mengetahui persentase pencapaian ketuntasan peserta.dapat dilihat pada tabel berikut ini:

Tabel 2. Hasil Interpretasi Skor

\begin{tabular}{llr}
\hline Tingkat & Kualifikasi & $\begin{array}{r}\text { Jumlah } \\
\text { peserta }\end{array}$ \\
\hline $81 \%-100 \%$ & Sangat Baik & 27 \\
$61 \%-80 \%$ & Baik & 10 \\
$41 \%-60 \%$ & Cukup & 0 \\
$21 \%-40 \%$ & Kurang & 0 \\
$0 \%-20 \%$ & Sangat & \\
\hline
\end{tabular}

\section{SIMPULAN DAN SARAN}

Simpulan

Berdasarkan hasil analisis data dapat ditunnjukkan peningkatan hasil belajar peserta menggunakan metode pada kegiatan pengabdian ini ditunjukkan dari persentase rata-rata pemahaman peserta terhadap pelatihan sebesar $84 \%$. Hasil Analisis tes hasil belajar untuk mengetahui persentase pencapaian ketuntasan peserta.sebesar $100 \%$.

Saran

Adapun saran yang dapat diberikan Berdasarkan pengamatan selama pelatihan,adalah perlunya pengembangan pelatihan untuk materi lain seperti perancangan jembatan, ragka atap, dsb untuk mengembangkan kompetensi peserta.

\section{UCAPAN TERIMA KASIH}

Ucapan terima kasih ditujukan kepada seluruh peserta yang ikut berpartisipasi pada kegiatan pengabdian ini, panitia yang telah mempersiapkan peralatan,dan perlengkapan selama kegiatan pengabdian berlangsung, serta ketua Prodi Teknik Sipil yang telah memberikan izin serta dukungan terselenggaranya kegiatan pengabdian Pelatihan SAP 
2000 Dalam Perencanaan Konstruksi Gedung Beton Bertulang Dan Baja Tahan Gempa Berdasarkan SNI 03-1726-2012.

\section{DAFTAR PUSTAKA}

Badan Standarisasi Nasional. 2012. SNI 1726:2012 - Tata Cara Perencanaan Ketahanan Gempa Untuk Struktur Bangunan Gedung. Bandung.

Badan Standarisasi Nasional. 2013. SNI 2847:2013 - Persyaratan Beton Struktural Untuk Bangunan Gedung. Bandung.

Dewobroto, W. 2014.Pemanfaatan Software Structural Analysis Program (SAP) sebagai media pembelajaran dalam mata kuliah Analisis Struktur. Lokakarya Jurusan Teknik SIpil Universitas Semarang.23 Oktober 2014, Gedung Graha Cendekia, Semarang.

Dewobroto, W. (2006). “Ilmu Rekayasa Klasik Sarana Menguasai Program Aplikasi Rekayasa - Studi Kasus: Mekanika Teknik Klasik dan Program SAP2000", Pembicara Utama dalam Seminar di Pameran Buku Konstruksi Indonesia 2006, R. Sapta Taruna, Gd. Utama Departemen Pekerjaan Umum, Jl. Pattimura 20, Sabtu, 2 Desember 2006.

Peraturan menteri pekerjaan umum dan perumahan rakyat Nomor 24/prt/m/2014.2014. Tentang Pedoman Pelatihan Berbasis Kompetensi Bidang Jasa Konstruksi.Jakarta.

Sabariman, Bambang. 2013. Pengembangan Media Video Tutorial Analisis Struktur Portal 3d Berbantuan Sap2000 Versi 15 (Studi Kasus) Di Jurusan Teknik Sipil Fakultas Teknik Universitas Negeri Surabaya UNESA. ejournal.unesa.ac.id/index.php/jurnal-kajian-ptb/article/view/2251. Diakses Tanggal 30 Agustus 2016.

Riduwan. 2010. Skala Pengukuran Variabel-Variabel Penelitian. Alfabeta. Bandung. Muhson,A. 2010. Teknik Analisis Kuantitatif. staff.uny.ac.id/sites/default/files/pendidikan/...\%20S..../Analisis\%20Kuantitatif.p df 